\title{
Impact of a cleaners' strike on compensation claims for asthma among teachers in Ontario
}

\author{
Marcos Ribeiro $\mathrm{MD}^{1,2}$, Larisa $\vee$ Buyantseva MD MS ${ }^{3}$, \\ Gary M Liss MD MS ${ }^{1,3}$, Carol E Luce BSc${ }^{4}$, Susan M Tarlo MB BS ${ }^{1,3}$
}

\begin{abstract}
M Ribeiro, LV Buyantseva, GM Liss, CE Luce, SM Tarlo. Impact of a cleaners' strike on compensation claims for asthma among teachers in Ontario. Can Respir J 2013;20(3):171-174.
\end{abstract}

BACKGROUND: A review of Workplace Safety and Insurance Board (WSIB) claims in Ontario from 1998 to 2002 showed an unusual spike in the number of claims accepted for work-exacerbated asthma (WEA) in April 2001.

OBJECTIVE: To identify the cause for the spike in the number of WSIB claims for WEA in April 2001.

METHODS: File reviews were performed to identify the occupations of workers with claims accepted for WEA in April 2001 compared with claims during March and May 2001, and during the same months in 2000 and 2002.

RESULTS: In April 2001, there were 61 accepted WEA claims; the most common occupation was 'teacher'. In contrast, among educational workers, there was only one WEA claim in the previous month and one in the following month. From March to May in the preceding and following years, there were only four and two claims, respectively. The most frequently implicated causative agents were dust and dirt exposure, which were responsible for $98 \%$ of claims; the mean $( \pm$ SD) number of lost workdays was $6.5 \pm 10$. The only identified environmental change associated with this spike was a cleaners' strike at all elementary and high schools in the Toronto District School Board in Ontario, which started on March 31, 2001 and ended on May 1, 2001.

CONCLUSION: The spike in accepted WEA claims in Ontario in April 2001 was temporally associated with a strike by Toronto District School Board cleaners, suggesting acute symptomatic effects of poor workplace (school) maintenance on asthmatic employees. The WSIB database was sufficiently sensitive to capture this phenomenon.

Key Words: Cleaners; Compensation claim; Strike; Toronto District School Board; Work-exacerbated asthma; Workplace Safety and Insurance Board

W ${ }^{\text {ork-related asthma (WRA), which includes occupational }}$ asthma (OA) and work-exacerbated asthma (WEA), represents a major health challenge, with significant potential for acute morbidity, long-term disability, and adverse social and economic impact $(1,2)$. A systematic analysis of recent studies (3) showed the overall median population-attributable fraction from occupation was $17.6 \%$. WEA is defined as asthma present before the work exposure but subsequently aggravated or exacerbated by conditions on the job (this can be chemical exposures, but could also include physical conditions such as changes in temperature or exertional demands) $(4,5)$.

In a previous report (6), we found that WEA comprised approximately $50 \%$ of accepted WRA compensation claims in Ontario and an even higher proportion in a recent review of claims (7). WEA claims are usually associated with a relatively short period of time missed from work $(8,9)$ and, unlike patients with OA, patients with WEA can often return to their usual workplace with adjustments to reduce exposures to probable airway irritants and/or with optimized asthma medication. Ontario is one of the few jurisdictions in Canada where WEA is compensable, in addition to OA.

\section{Les effets d'une grève des concierges sur les réclamations d'indemnisation pour l'asthme de la part des enseignants de l'Ontario}

HISTORIQUE : Une analyse des réclamations à la Commission de la sécurité professionnelle et de l'assurance contre les accidents du travail (CSPAAT) de l'Ontario entre 1998 et 2000 a révélé un pic inhabituel du nombre de réclamations acceptées en raison d'un asthme exacerbé par le travail (AET) en avril 2001.

OBJECTIF : Déterminer la cause du pic du nombre de réclamations à la CSPAAT en raison d'un AET en avril 2001.

MÉTHODOLOGIE : Les chercheurs ont analysé les dossiers pour déterminer l'emploi des travailleurs dont la réclamation d'AET avait été acceptée en avril 2000 à celles déposées en mars et en mai 2001 et au cours des mêmes mois en 2000 et 2002.

RÉSULTATS : En avril 2001, 50 réclamations d'AET ont été acceptées. La profession la plus courante était celle d'enseignant. Par contre, une seule déclaration d'AET avait été déposée au cours du mois précédent ou du mois suivant. De mars à mai de l'année précédente et de l'année suivante, les chercheurs ont comptabilisé seulement quatre et deux réclamations, respectivement. L'exposition à la poussière était l'agent causal le plus signalé, car il était responsable de $98 \%$ des réclamations. En moyenne ( \pm ÉT), les travailleurs perdaient $6,5 \pm 10$ journées de travail. Le seul changement environnemental lié à ce pic était une grève des concierges de toutes les écoles primaires et secondaires du conseil scolaire du district de Toronto, en Ontario, qui a commencé le 31 mars 2000 et s'est terminée le $1^{\text {er }}$ mai 2001.

CONCLUSION : Le pic des réclamations d'AET acceptées en Ontario en avril 2001 s'associe dans le temps à une grève des concierges du conseil scolaire du district de Toronto, ce qui laisse croire aux effets symptomatiques aigus du mauvais entretien du milieu de travail (l'école) sur les patients asthmatiques. La base de données de la CSPAAT était assez sensible pour saisir ce phénomène.

Workers' compensation claim records are often used as a source of information in surveillance and planning for occupational health protection in countries where large proportions of the working population are covered by similar insurance programs (10).

A review of Workplace Safety and Insurance Board (WSIB) claims in Ontario from 1998 to 2002 showed an unusual peak in claims accepted for WEA in April 2001. In the present study, we explored the cause for this.

\section{METHODS}

The study protocol was reviewed and approved by the Research Ethics Board of the University of Toronto, Toronto, Ontario. All accepted WSIB claims for asthma were included in a file review. From the occupational disease database of the WSIB, claims that contained primary diseases that included asthma for which the 'date of accident' was between January 1998 and December 2002 (five consecutive years) were initially identified. The 'date of accident' was the date that is identified in the WSIB file as the date of onset of the work-associated symptoms. Information from each eligible claim file in the WSIB

${ }^{1}$ University of Toronto, Toronto, Ontario; ${ }^{2}$ Pulmonary Division, Heart Institute (InCor) - University of São Paulo, São Paulo, Brazil; ${ }^{3}$ Gage

Occupational and Environmental Health Unit, Dalla Lana School of Public Health, University of Toronto; ${ }^{4}$ Ontario Workplace Safety and

Insurance Board, Toronto, Ontario

Correspondence: Dr Susan M Tarlo, Toronto Western Hospital, East Wing 7-449, 399 Bathurst Street, Toronto, Ontario M5T 2 S8.

Telephone 416-603-5177, fax 416-603-6763, e-mail susan.tarlo@utoronto.ca 


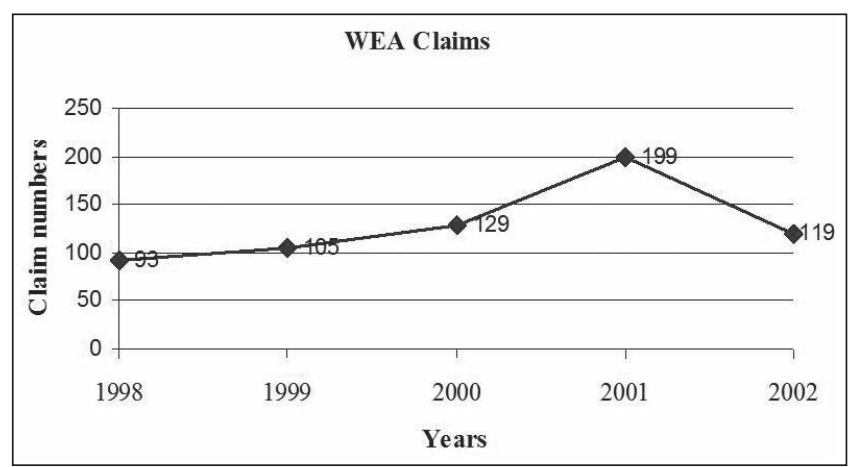

Figure 1) Yearly numbers of accepted work-exacerbated asthma (WEA) claims from 1998 to 2002 in Ontario

database was extracted using the questionnaire form described and refined in previously published studies $(6-8,11,12)$. The extent of available information in the files varied, with more detailed information generally present for chronic work-related symptoms and less medical information for transient WRA symptoms. All accepted asthma claim files contained demographic data (date of birth, sex, occupation), and most had information on exposure history including agents and duration; history of previous asthma before starting job; history of nasal, eye, and lower respiratory symptoms and their frequency; clinical diagnosis made by the most specialized assessing physician; WSIB decision; and objective tests (spirometry, peak flow studies, methacholine challenge tests, skin tests to common allergens and workplace substances, if available).

For the current report, all allowed asthma claims that were considered to be WEA were analyzed. The criteria used in the present study were the presence of pre-existing asthma (present before starting the job for which the WSIB claim had been initiated); and exacerbation of symptoms at work that were not identified as being due to new specific sensitization to a workplace agent.

The present study was observational and retrospective in nature, and compared accepted compensation WEA claims during April 2001 with the month before and month after, and the same period for the year before and after 2001 .

\section{Analysis}

Data analyses were performed using SAS version 9.1 (SAS Institute, USA). Continuous variables are expressed as mean $\pm \mathrm{SD}$, and categorical variables are expressed as frequencies or percentages.

\section{RESULTS}

During the five-year time period of the present review, 1738 claims were submitted for compensation as WRA. Among these, 893 were accepted, of which 645 (72\%) fulfilled the present study's criteria for WEA. During 2001, there were 199 claims accepted for WEA in Ontario, compared with 129 claims in 2000 and 119 claims in 2002 (Figure 1). Yearly rates for compensated OA were stable during this time (data not shown).

There was a peak in WEA claims in April 2001, accounting for $61(31 \%)$ of the 199 total claims for WEA in 2001. When the numbers from one year before and after, for the same month were compared, there were seven claims in April 2000 and 17 claims in April 2002 (Table 1).

It was speculated that the education sector was responsible for this increase in the number of accepted WEA claims in 2001. In the education sector, there were 48 claims in April 2001 and the most common occupation among WEA claims during this month was 'teacher'. There were 47 individuals classified as teachers (elementary, $n=44$; secondary, $n=3$ ), with one individual classified as a school secretary. In contrast, there was only one WEA claim among teachers in the previous (March) and following (May) months in 2001. From March through May in the preceding and following years, there were only four and two claims, from the education sector, respectively (Table 1). Similarly, in 1998 between March and May there was only one claim and, in 1999, during the same period, there were four claims in March and one claim in May, with no claims in April. There were no differences in sex, age, previous time worked and lost workdays when these claims were compared between years. From March through May 2001, the most frequent self-reported causative agents were dust and dirt exposure, which were responsible for $98 \%$ of the 50 claims, with a mean ( \pm SD) number of lost workdays in April 2001 of $6.5 \pm 10$ (Table 1).

For the April 2001 period, $81 \%$ of the subjects were assessed by their family physicians and $10 \%$ by emergency medicine doctors. At the time the claim was submitted, the vast majority of these subjects did not undergo any objective test (skin prick test, pulmonary function or methacholine challenge) related to the exacerbation of asthma symptoms. Ninety-two per cent of these individuals had a previous history of asthma (this information was not recorded in $8 \%)$. Thirty-one per cent and $17 \%$ of the subjects, respectively, reported an increase in upper airway symptoms and ocular symptoms during that period.

The only identified environmental change associated with this peak was a cleaners' strike at all elementary and high schools in the Toronto District School Board (TDSB) in Ontario that started on March 31, 2001, and ended on May 1, 2001.

\section{DISCUSSION}

Our study found a spike in accepted WEA claims in Ontario in April 2001, which were filed primarily from teachers and was temporally associated with a strike by TDSB cleaners, suggesting acute symptomatic effects of poor workplace (school) maintenance on asthmatic employees.

A study from Manitoba (13) found that teaching and related occupations (this group includes teachers in community colleges, vocations and the arts) was one of the three groups of occupations found to have elevated odds for physician-diagnosed asthma (OR 2.54 [95\% CI 1.18 to 5.44]). The presence of mould and other fungi in the damp school or office environments has been associated with the development of respiratory symptoms, and affects both students and teachers (14). Dust and poor indoor air quality represented the most frequent putative causes of WRA in a study involving teachers (15). Our findings are also consistent with a report (16) that identified cases of WRA from the educational services industry as reported to four states in the Sentinel Event Notification System for Occupational Risks (SENSOR). Nine per cent of all WRA cases reported were from this industrial sector, of which approximately one-third were classified in their system as work-aggravated asthma rather than new-onset asthma. Most cases were teachers and teachers' aides, and the most common self-implicated exposures for those who had WEA were to mould, dust and indoor air pollutants. The amount of time missed from work and the duration of the asthma 'aggravation', however, were not reported (17).

In contrast to claims for irritant-induced OA (including reactive airways dysfunction syndrome), most compensation claims for workaggravated asthma or WEA are for a short period of time off work (8), consistent with the present findings in which the mean time off work for WEA associated with the strike of maintenance workers was 6.5 days.

The TDSB has approximately 31,000 permanent and 8000 temporary staff, which included 10,000 elementary school teachers and 5800 at the secondary level in 2001, teaching more than 300,000 students. The TDSB did not close the elementary and high schools during the strike.

The present study had limitations that should be addressed. The estimation of WEA using compensation data may be incomplete due to cases not being recognized and/or reported by workers, and potential reluctance to submit claims. A recent report of work-related accidents assessed in emergency departments in Ontario (18) found 
TABLE 1

Total number of all accepted claims and claims among education workers for work-exacerbated asthma (WEA) during March, April, and May 2000 to 2002, extracted from the Workplace Safety and Insurance Board (Ontario)

\begin{tabular}{|c|c|c|c|c|c|c|c|c|}
\hline \multirow[b]{2}{*}{ Variable } & \multicolumn{4}{|c|}{ All claims $(n=158)$} & \multicolumn{4}{|c|}{ Education workers $(n=56)$} \\
\hline & 2000 & 2001 & 2002 & $P^{*}$ & 2000 & 2001 & 2002 & $P^{*}$ \\
\hline Claims, \% & $17.7(n=28)$ & $57.6(n=91)$ & $24.7(n=39)$ & 0.037 & $7(n=4)$ & $89(n=50)$ & $4(n=2)$ & 0.0004 \\
\hline Sex ${ }^{\dagger}$, male/female, $\mathrm{n} / \mathrm{n}(\% / \%)$ & $8 / 20(29 / 71)$ & $27 / 63(30 / 70)$ & $12 / 27(31 / 69)$ & 0.981 & $1 / 3(25 / 75)$ & $12 / 37(25 / 75)$ & $0 / 2(0 / 100)$ & 0.725 \\
\hline Age, years, mean $\pm S D$ & $50 \pm 11$ & $45 \pm 11$ & $45 \pm 11$ & 0.174 & $52 \pm 5.3$ & $46.6 \pm 10.1$ & $59 \pm 11$ & 0.161 \\
\hline Previous time worked, years & $13.7 \pm 8.4$ & $13.8 \pm 8.5$ & $11.7 \pm 6.4$ & 0.385 & $16 \pm 4.2$ & $17.6 \pm 8$ & $20 \pm 3.2$ & 0.830 \\
\hline WEA claims (March), n (\%) & $13(46.4)$ & $16(17.6)$ & $15(38.5)$ & 0.721 & $2(50)$ & $1(2)$ & $1(50)$ & 0.216 \\
\hline WEA claims (April), n (\%) & $7(25)$ & $61(67)$ & $17(43.6)$ & 0.0008 & $2(50)$ & $48(96)$ & $1(50)$ & 0.0009 \\
\hline WEA claims (May), n (\%) & $8(28.6)$ & $14(15.4)$ & $7(17.9)$ & 0.001 & $0(0)$ & $1(2)$ & $0(0)$ & 0.764 \\
\hline Lost work days, mean \pm SD & $30.1 \pm 126$ & $5.0 \pm 8.2$ & $4.4 \pm 12.7$ & 0.078 & $7.1 \pm 4.5$ & $6.5 \pm 10$ & $10.5 \pm 15$ & 0.841 \\
\hline \multicolumn{9}{|l|}{ Causative agents } \\
\hline Dust and dirt exposure, n (\%) & & & & & $0(0)$ & $49(98)$ & $0(0)$ & $\leq 0.0001$ \\
\hline Other ${ }^{\ddagger}, \mathrm{n}(\%)$ & & & & & $4(100)$ & $1(2)$ & $2(100)$ & 0.031 \\
\hline
\end{tabular}

${ }^{*} \chi^{2}$ analysis and ANOVA; ${ }^{\dagger}$ Data missing for one claim; ${ }^{\ddagger}$ Other: construction/renovation dust $(n=2)$, chemical not otherwise specified ( $\left.n=1\right)$, second-hand smoke ( $\left.n=1\right)$, cleaning agents ( $n=1)$, mould ( $n=1)$ and other fumes/odours $(n=1)$

that only approxiamtely $40 \%$ resulted in workers' compensation claims. The analyses in the present study were also limited by the amount of data available in the compensation claim files, especially for those with more transient exacerbations, many of which included data only from an emergency department visit or primary care physician, in contrast to the greater detail usually found in the files of individuals with claims accepted for OA. In many cases, especially those that are transient, the diagnosis was based on the history of transient worsening of asthma related to work, without objective tests to confirm a work relationship. Details of any unusual exposure conditions leading to the exacerbation were also very limited. Our data were limited to the information in the compensation files and we were not able to obtain additional information regarding these aspects for further analyses.

Other potential environmental causes of asthma exacerbations leading to the spike in claims are unlikely because the unusual rise in claims appears to be confined to the educational sector and was not apparent among outdoor workers or other occupations. However, it is possible that psychological factors may have contributed to time off work and compensation claims among teachers during the strike. This could not be addressed in more depth by our review of compensation files.

We are not aware of previous reports of WRA or other health effects resulting from a cleaners' strike in schools. The present study reports two principal findings: first, it can be retrospectively established that the WSIB data system was sufficiently sensitive to detect this phenomenon; and, second, that the peak of WEA claims among teachers in Ontario in April 2001 was likely due predominantly to dust and dirt exposure resulting from the absence of cleaning during the TDSB cleaners' strike.

\section{Key points}

- A spike of accepted WEA claims in Ontario in April 2001 was temporally associated with a strike by TDSB cleaners.

- The WSIB (compensation board) data system was sufficiently sensitive to capture this phenomenon.

ACKNOWLEDGEMENTS: MR was involved with the analyses and interpretation of results, and writing the manuscript. LVB was involved with data collection and writing the manuscript. GML conceived the study, was involved with the analyses and interpretation of results, and writing the manuscript. CEL assisted with the interpretation of the results and review of the manuscript. SMT conceived the study, was involved with the analyses and interpretation of results, and writing the manuscript. All co-authors approved the final manuscript. The authors thank Ms Lee Vernich from the Research Services Unit (RSU), Dalla Lana School of Public Health, University of Toronto for performing the statistical analyses.

FUNDING: This study was funded, in part, by a grant from the Research Advisory Council of the Ontario Workplace Safety and Insurance Board. Dr Ribeiro was supported in part by Coordenação de Aperfeiçoamento de Pessoal de Nível Superior (CAPES), Brazil.

DISCLOSURES: SMT provided medical consultations for patients referred by the Ontario Workplace Safety and Insurance Board in addition to research study support (peer reviewed) and workshop support. The other co-authors have no financial disclosures or conflicts of interest to declare.

\section{REFERENCES}

1. Tarlo SM, Rowe B, Liss GM, Lemiere C, Beach J. Consensus on work-related asthma. Occup Med 2009;59:213-5.

2. Balmes J, Becklake M, Blanc P, et al. American Thoracic Society Statement: Occupational contribution to the burden of airway disease. Am J Respir Crit Care Med 2003;167:787-97.

3. Toren K, Blanc PD. Asthma caused by occupational exposures is common - a systematic analysis of estimates of the populationattributable fraction. BMC Pulm Med 2009;9:7.

4. Tarlo SM, Balmes J, Balkissoon R, et al. Diagnosis and management of work-related asthma: American College Of Chest Physicians Consensus Statement. Chest 2008;134:1S-41S.

5. Henneberger PK, Redlich CA, Callahan DB, et al. An official American Thoracic Society statement: Work-exacerbated asthma. Am J Respir Crit Care Med 2011;184:368-78.

6. Tarlo SM, Liss GM, Corey P, Broder I. A workers' compensation claim population for occupational asthma: Comparison of subgroups. Chest 1995;107:634-41.

7. Buyantseva LV, Liss GM, Ribeiro M, Manno M, Luce CE, Tarlo SM. Reduction in diisocyanate and non-diisocyanate sensitizer-induced occupational asthma in Ontario. J Occup Environ Med 2011;53:420-6.

8. Chatkin JM, Tarlo SM, Liss G, Banks D, Broder I. The outcome of asthma related to workplace irritant exposures: A comparison of irritant-induced asthma and irritant aggravation of asthma. Chest 1999;116:1780-5.

9. Santos MS, Jung H, Peyrovi J, Lou W, Liss GM, Tarlo SM. Occupational asthma and work-exacerbated asthma: Factors associated with time to diagnostic steps. Chest 2007;131:1768-75

10. Smith PM, Stock SR, McLeod CB, Koehoorn M, Marchand A, Mustard CA. Research opportunities using administrative databases and existing surveys for new knowledge in occupational health and safety in Canada, Quebec, Ontario and British Columbia. Can J Public Health 2010;101:S46-S52. 
11. Tarlo SM, Banks D, Liss G, Broder I. Outcome determinants for isocyanate induced occupational asthma among compensation claimants. Occup Environ Med 1997;54:756-61.

12. Tarlo SM, Liss GM, Yeung KS. Changes in rates and severity of compensation claims for asthma due to diisocyanates: A possible effect of medical surveillance measures. Occup Environ Med 2002;59:58-62.

13. Kraut A, Walld R, Mustard C. Prevalence of physician-diagnosed asthma by occupational groupings in Manitoba, Canada. Am J Ind Med 1997;32:275-82.

14. Hardin BD, Kelman BJ, Saxon A. Adverse human health effects associated with molds in the indoor environment. J Occup Environ Med 2003;45:470-8.
15. Fletcher AM, London MA, Gelberg KH, Grey AJ. Characteristics of patients with work-related asthma seen in the New York State Occupational Health Clinics. J Occup Environ Med 2006;48:1203-11.

16. Mazurek JM, Filios M, Willis R, et al. Work-related asthma in the educational services industry: California, Massachusetts, Michigan, and New Jersey, 1993-2000. Am J Ind Med 2008;51:47-59.

17. Tarlo SM. Occupational exposures and adult asthma. Immunol Allergy Clin N Am 2008;28 563-76.

18. Mustard CA, Chambers A, McLeod C, Bielecky A, Smith PM. Comparison of data sources for the surveillance of work injury. Occup Environ Med 2012;69:317-24. 


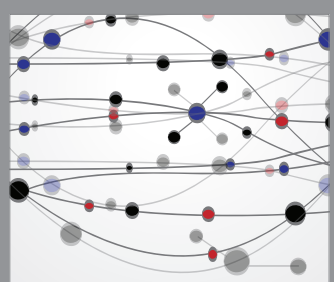

The Scientific World Journal
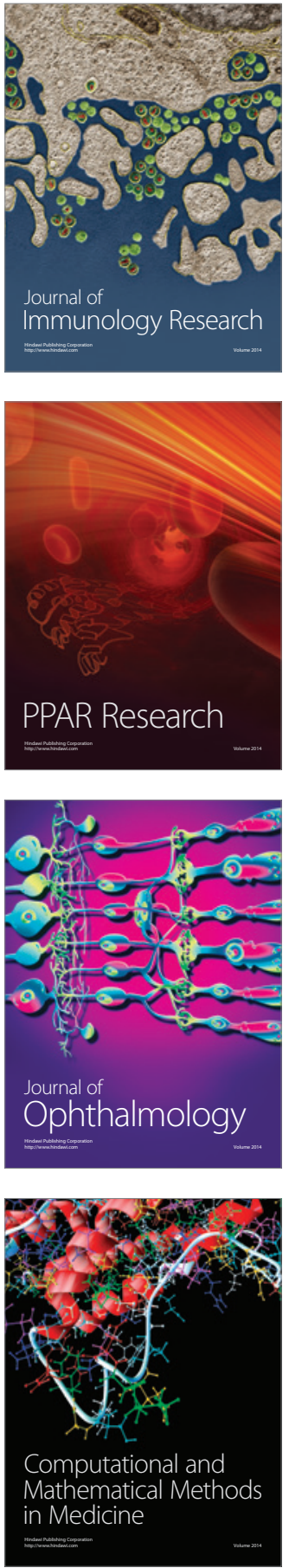

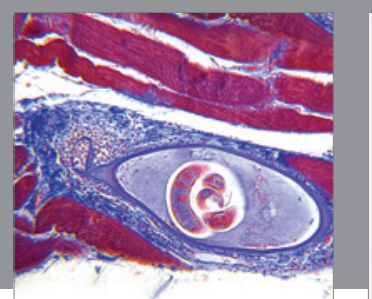

Gastroenterology Research and Practice

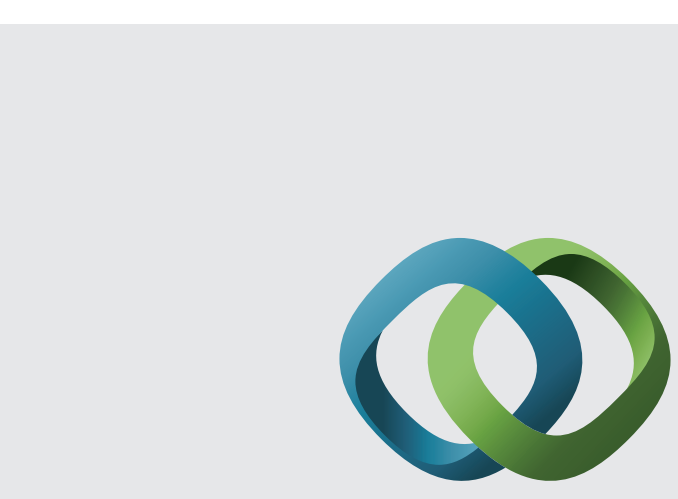

\section{Hindawi}

Submit your manuscripts at

http://www.hindawi.com
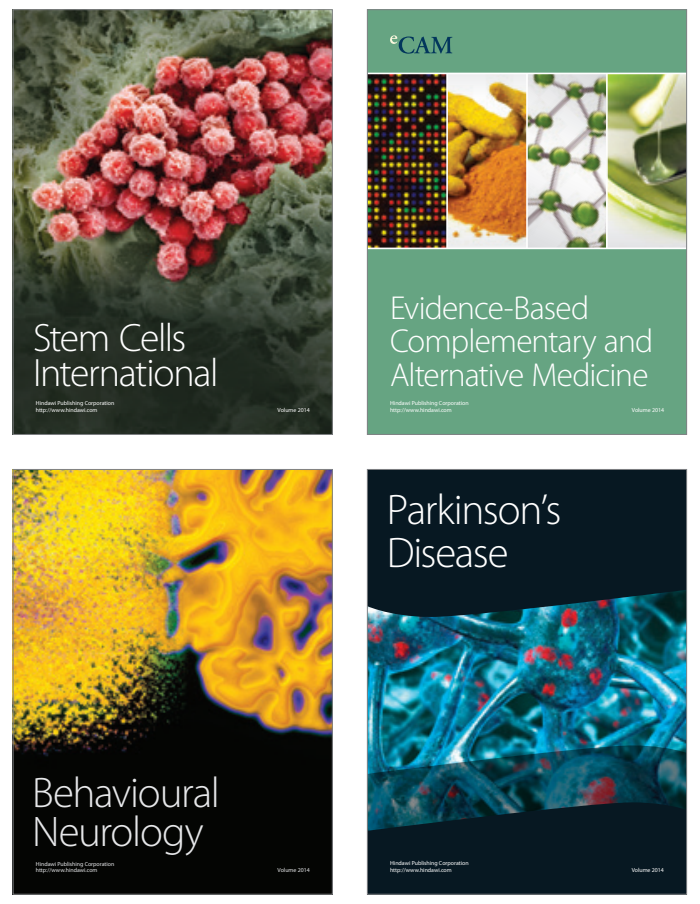
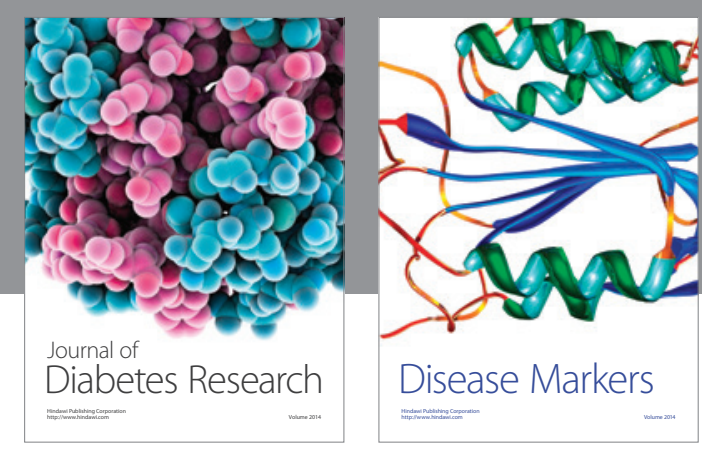

Disease Markers
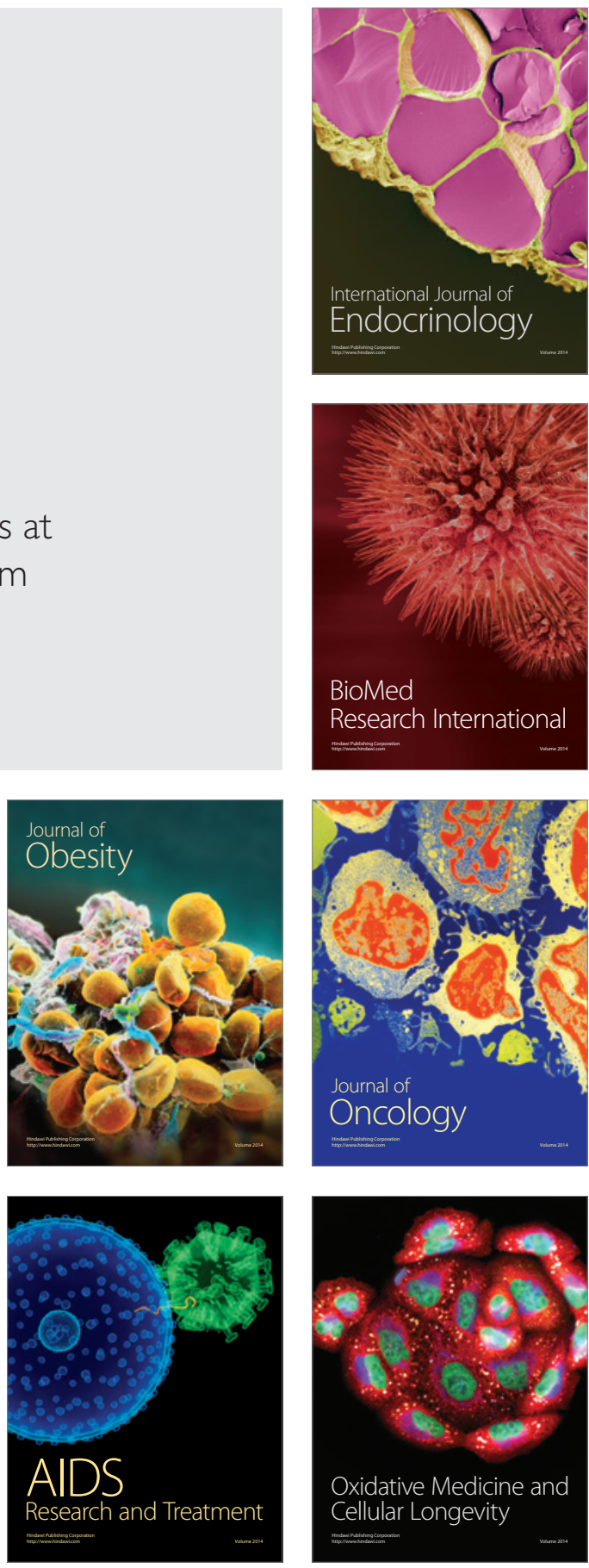